Jakob Cromdal and Michael Tholander

Department of Social and Welfare Studies

Linkoping University

60174 Norrkoping

Sweden

+4611363618

jakob.cromdal@liu.se

Title:

Introduction: Morality in professional practice

Running head:

Morality in professional practice

Word count:

3648

Character count:

24280

Bionotes:

Jakob Cromdal is professor in educational practice at the Department of Social and Welfare Studies, Linköping University, Sweden. His research focuses on talk and social interaction among children and youth in a variety of mundane and institutional settings, including playgrounds, classrooms, detention homes and calls to the emergency services. Department of Social and Welfare Studies, Linkoping University, 60174 Norrkoping, Sweden, jakob.cromdal@liu.se

Michael Tholander is associate professor at the Department of Behavioral Sciences and Learning, Linköping University, Sweden. His main field of interest is research on school interaction, with a special focus on issues such as socialization and morality, democracy and participation, and assessment and evaluation. Department of Behavioral Sciences and Learning, Linköping University, 581 83, Linköping, Sweden, michael.tholander@liu.se 


\title{
Introduction: Morality in professional practice
}

\author{
Jakob Cromdal \& Michael Tholander \\ Linköping University, Sweden
}

\begin{abstract}
"Morality is such a common and intrinsic quality of everyday social interaction that it is usually invisible to us, like glasses that provide a sharp sight of the area beyond although they themselves remain unseen.” (Bergmann 1998: 280)
\end{abstract}

This special issue of the Journal of Applied Linguistics and Professional Practice presents a collection of articles that explores moral work in professional practice. In the broadest sense, the focus is on people 'doing morality' with regard to prior, and somehow problematic, events. Our goal is to illustrate how morality forms part and parcel of the work of professionals; how moral orders are drawn upon, and how they are reflexively shaped and accomplished in and through real interactional events taking place in different institutional encounters. For this reason, the studies in this special issue take an empirically sound, practice-oriented approach to morality-in-interaction.

Over the years, human morality has become a locus of much scholarly work involving a multitude of academic disciplines, theories and methodological approaches that have 
generated a bulk of knowledge far too great to be reviewed here. Three general features, however, stand out in this body of academic work.

First, research into morality is very rarely based on naturally ocurring data. With the exception of moral philosophy, where empirical data are largely absent, studies of moral issues typically rely on interviews, tests and other research instruments that measure morality retrospectively. Thus, such research procedures tend to overlook the situated, contingent nature of moral life. Second, most approaches treat human morality as something residing within the individual; as a mental capacity of reasoning and making judgments on moral issues and as a character trait. By locating morality to the individual's mind, such studies neglect the ways in which social actors handle themselves in practical settings. What is lost, then, is the social, contextually anchored, production of moral order. Third, most empirical analyses take on board preconceptualised notions of morality - typically originating in such frameworks as Kantian duty-based ethics, Benthamian utilitarianism or Aristotelian virtue ethics. Thus, rather than examining what sense of morality is being practiced and accomplished by lay or professional members in society, morality is reduced to a predetermined set of conventions and values - a theoretical construct.

Of course, the notion of morality as a set of more or less omnirelevant values stored 'in the head', as a feature of our mental inventory, is not exclusive to psychologists or philosophers or any other scholarly group. It is very much part of our lay conceptions of the human personality, at least in Western cultures. As Bergmann points out:

In everyday life morality refers to internal attitudes and processes. Conscience is seen as part of the 'inner man', and an 'inner voice' is telling us that we have violated rules that we have internalized. Thus, philosophical perspectives that 
conceptualize moral judgment as running from the inside to the outside reproduce the commonsense notion of morality (1998: 282).

Members are biased towards understanding behaviour in terms of underlying mentaldispositional structures. The moral aspects of human conduct are therefore seen as causally linked to individual character traits and cognitive structures; social action provides members with materials for ascribing character. Just how that ascription is accomplished by members forms 'the most salient feature of the "lived” morality of everyday life - its practical character' (Bergmann 1998: 281). What is needed, then, is a solid empirical approach to investigating the real-life practices through which people relate to, engage in, and co-produce social and moral orders.

The articles in this special issue offer just that: they examine how moral orders are identified, invoked and acted on by members going about their business within professional settings. For instance, issues of accountablity and ascriptions of motive as well as justification, are brought to the fore by Elizabeth Stokoe and Derek Edwards, who focus on complaints in neighbourhood disputes. They examine a community mediation session in which two couples complain about the children of their joint neighbour. These complaints draw on cultural notions of familial-parental duties. Specifically, they invoke 'natural' attributes of mothering and this 'naturalness' is oriented to within a moral framework, such that any mother who is seen not to behave according to the norms of their category can be judged as immoral. Stokoe and Edwards' analysis thus demonstrates how members’ categorization practices work to assemble a version of the social and moral order in which mothers, not fathers, are accountable for maintaining good neighbour relations.

Another organised setting that is rich in morally loaded discourse is family therapy. The article by Karin Aronsson draws on video recorded family therapy sessions, involving two teenage clients who have been referred for treatment due to their putatively troublesome 
behaviour. Aronsson's analysis discusses various features of the talk - including the ways in which the client's problem is presented, received and accounted for - within an 'architecture of blame’ that entails members' management of accountability.

The article by Annice Barber focuses on the negotiation of moral identities for at-risk urban adolescents in a religious community youth organization. Specifically, Barber shows how teens and adult leaders jointly co-construct a framework for judging the morality of thoughts and actions through imaginative collated narratives. This discursive practice involves comparing some behaviour with an exemplar narrative, where Jesus is the protagonist (e.g., “What would Jesus do?”) and Barber’s analysis demonstrates how such moral lessons, portrayed as finely tuned balancing acts, aim to socialise the young people into a Christian moral framework.

The final two articles examine telephone calls to helplines dedicated to children and young people. Jonathan Potter and Alexa Hepburn's study draws on an archive of calls to the NSPCC (the UK National Society for the Prevention of Cruelty to Children). The issue of morality is a pervasive one in calls to this helpline: what is or is not acceptable or normal, and what is legal or illegal, are central concerns of both callers and child protection officers. Potter and Hepburn's analysis is concerned with the child protection officers' reciepts of and responses to reports of child abuse. In particular, they observe that the child protection officers typically withold explicit expression of sympathy with the victim or condemnation of the perpetrator - thus resisting to engage in what Stokoe and Edwards (this issue) have termed 'mundane morality.' Potter and Hepburn discuss their findings in terms of the child protection officers' focus on the practical tasks at hand: of establishing a clear sense of what has happened so as to be able to offer help and guidance, but also of taking the report seriously (and doing so in a manner that is recognisable for the caller) without prematurely buying into their factuality. 
Finally, in the article by Susan Danby and Michael Emmison we learn how a young caller to the Australian Kids Helpline reports how she forged a medical certificate and handed it in to her teacher. The authors show how the young caller determines what to report, how to report it, and how the moral work of the troubles talk is delicately managed by both caller and counselor. While the caller's account is partly about deception, the analysis shows how both parties delicately sidestep naming this action in such terms. One way of achieving this is by making it a character puzzle. The caller, from the very beginning of the call, seeks to find out why she could have done this (“you see I don’t know why it happened”), and as the call unfolds the counselor follows this opening query and engages, together with the caller, in a search for different possible motives for this action - other than deception. Danby and Emmison's article thus shows how the caller can bring possibly morally damaging evidence to this telephone service and seek support without being held morally accountable for what she has done.

Historically, the type of approach to morality that we are advocating in this special issue may be found within ethnomethodology, conversation analysis, and discourse analysis. A classical example is Sacks' (1972) study of how the police go about inferring 'moral character' and 'probability of criminality', from persons' appearance on the street, thereby legitimizing actions such as questioning, search and even arrest. This results in a type of moral game in which the criminals orient toward using appearances to avoid recognition, while the police try to see through such masking. For both parties, it would therefore seem rational to develop a form of visual moral expertize.

Another early example is Wieder’s (1974) research at a halfway house. He focused on the so called 'convict code' at the institution and shows, among other things, that a simple question from a resident to the staff, e.g., "Where can I find that meeting where I can get an overnight pass?” (p. 160), accomplishes important moral work. Wieder argues that this 
question conveys to the overhearing residents that the speaker is only going to the meeting to collect the reward, not because he is interested in participating in the program offered by the officials. Through such utterances, Wieder argues, residents display their independence in relation to the institution and do so without explicitly referring to the convict code. Moreover, the example also cautions analysts against the temptation of using the code as an explanatory variable; the code does not explain or predict residents’ behavior, as one might be lured into thinking, but rather exhibits moral norms in their making. Thus, to understand the moral life at the halfway house, it makes little sense to try to abstract or formulate the convict code only to dissect it in its immediate, occassioned use.

These early studies have been followed by many others, each tapping into distinct institutional settings and each, more or less explicitly, focusing on morality-in-interaction. In a legal setting, Drew (1992) shows that disputing parties are often acutely oriented toward managing the damaging moral implications of contrasting versions of the same event. Thus, in sophisticated ways, participants routinely try to undermine alternative versions and bolster their own. This might occasionally lead to endless series of blamings and blame reallocations, as shown in Ingrids' (2014) study of child custody disputes. Harris (2001) also shows that there are good reasons, in this kind of moral work, to establish various sorts of implicatures which the jury must work out. Whereas direct portrayals of events and personal characteristics run the risk being seen as adversarial rhetoric, implicatures call upon juries to interpret the evidence for themselves and to reach their own judicial conclusions. The moral essence of trials, decision on guilt and innocence, can thus respectfully be reserved for the correct party. In a medical setting, Maynard (1996) shows that the delivery of bad news, e.g., the death of a loved one or negative diagnostic information, is a delicate moral activity for physicians. Thus, through various forms of forecasting practices, e.g., solemn demeanors, preannouncements, and stallings, they often try deliver bad news in morally responsible manner. 
Bergmann (1992) also shows that psychiatrists often proceed in careful, indirect ways when they explore the mental condition of their patients, hence producing a sort of 'veiled morality'. Similarly, genetic counsellors often adopt 'an ethos of nondirectiveness' which, rather than being a sign of moral indifference, provides them with a means of exploring whether clients can be trusted to make autonomous decisions (Arribas-Ayllon \& Sarangi, 2014).

In a social-work setting, Sacks (1992), analyzed how a social worker and a husband in marital troubles negotiate what 'really' happened in a domestic dispute with his wife. Sacks shows how different morally loaded category-implicative action descriptors - 'smacked her', 'shoved her', ‘moved her' - were used to characterize what the husband presumably had done to his wife. The social worker would lean toward 'smacking', whereas the husband would insist on 'moving' the wife. Eventually, they would settle for the husband's having 'shoved' his wife. Similar attentiveness to the moral tenor of a story is also displayed in a young man's narratives of past violence (Andersson, 2008). These narratives were structured so that the young man, a resident in forced care, managed to avoid being categorized as either victim or perpetrator. Instead, he construed himself according to a heroic storyline in which he, as the underdog, managed to handle adversaries much larger than his own size. As Wetherell and Edley (1999) point out, the creation of such a heroic position can be seen as a self-exalting strategy. Finally, Osvaldsson's (2011) analysis of accounts of bullying on an virtual board for peer-counselling demonstrates how social and moral orders are invoked and acted on by members of an internet community.

In a school setting, Svahn and Evaldsson (2013) show how alternative moral stances are talked into being, and made sense of, in Aggression Replacement Training (ART) classroom sessions. As the children discuss the morally charged topic of 'fighting', they artfully design their contributions in a way that allows them both to comply with and simultaneously subvert 
the institutional moral standards. Moving away from hypothetical cases in ART sessions, Theobald and Danby (2012) examine how two boys account for a playground incident when confronted by a supervising teacher. The analysis unpacks the elaborate interactional work involved in discussing the incident, showing how the teacher's version of proper moral playground conduct is eventually established. However, many school studies also show that children are highly capable of creating their very own moral worlds, e.g., through teasing (Thorne, 1993), gossip (Tholander, 2003), or telling stories (Goodwin, 1990).

Finally, morally loaded conversations have been analysed in emergency-service settings. For instance, Whalen et al. (1988) focus on a single telephone conversation between a caller and an emergency operator, which ends in the caller's stepmother dying. The case in itself caused a moral uproar in the local media in Dallas, USA, in early 1984, but the moral order can also be understood from within the interaction between the parties. A central observation in the study is that the dispute that develops between the caller and emergency operator is caused by the different expectations that the parties bring to the call. The caller, expecting a swift service, insists on having an ambulance dispatched immediately, while the emergency operator, who is committed to the task of running a service with limited resources, works at length to have the caller's need for help confirmed before initiating dispatch. This leads to a breakdown in conversational alignment and results in an off-task, hostile, morally loaded argument between the parties. Twenty-six years later, a similar case occurs in Oslo, Norway, causing the same massive press coverage (Svennevig, 2012). Thus, rather than working up ‘thick-enough descriptions’, which Cromdal et al. (2007) argue is essential for a timely dispatch of emergency rescue services, the participants in these emergency calls digress into deadly side-activities.

Naturally, moral discourse regularly appears in relation to a number of other institutional settings (involving various professionals, clients, dilemmas, etc.) apart from those 
mentioned above, e.g., in health visitors atrocity stories (Dingwall, 1977), in provocative news interviews (Clayman, 1992), in gossip at work or with friends (Bergmann, 1993), in evaluative dialogues with conscientious objectors (Adelswärd, 1998), in vocational guidance conversations (Mäkitalo, 2006; Persson-Thunqvist, 2003), in academic data sessions (Antaki et al., 2008), in editorial journalists’ accounting practices (Tileagă, 2010), in vocational rehabilitation encounters (Solberg, 2011), in community groups for the development of deprived inner-city areas (Patterson et al., 2011), in parents’ stories of preschool choice (Karlsson et al., 2013), in assessment conferences at detention homes (Aronsson \& Osvaldsson, 2013), in victims accounts of police manners during catastrophic events (Cocking \& Drury, 2014), or in performance-appraisal dialogues (Sandlund, 2014).

These studies have all shed some light onto the moral wor(l)ds of institutions, and have yielded new repertoires of analytical concepts for future use. The aim of this special issue is to contribute to and elaborate this growing body of work. The articles included in the issue show how parties to institutional encounters read into one another's actions such matters as consciousness, intention, moral attitude and character - and display their understandings as part and parcel of participating in their interactions. For instance, when engaging in agreements or disagreements, when questioning or accounting for certain forms of behaviour, when praising, blaming or otherwise assessing their own and one anothers' actions, members invariably invoke and reflexively produce moral orders. Paraphrasing Linell and Rommetveit (1998: 466), it is in and through dialogue that human beings constitute themselves as moral agents. Thus, the line of inquiry advanced in this special issue does not seek the bedrock truth about moral values. Rather, it reveals to us "values-in-use, beliefs-in-context, judgments-inpractical-settings etc.” (Jayyusi 1991: 233) and other matters as they surface in local exchanges between persons doing the work of some of society's institutions. 


\section{References}

Adelswärd, V. (1998) Moral dilemmas and the moral rhetoric in interviews with conscientious objectors. Research on Language and Interaction 31 (3/4): 439-464.

Andersson, K. (2008) Constructing young masculinity: A case study of heoric discourse on violence. Discourse and Society 19 (2): 139-161.

Antaki, C., Biazzi, M., Nissen, A. \& Wagner, J. (2008) Accounting for moral judgments in academic talk: The case of a conversation analysis data session. Text and Talk 28 (1): 1-30.

Aronsson, K. \& Osvaldsson, K. (2013) Trust and the contestation of blame narratives: veiled stances in an institutional assessment context. In P. Linell and I. Marková (eds) Dialogical Approaches to Trust in Communication, 29-49. Charlotte: Information Age Publishing.

Arribas-Ayllon, M. \& Sarangi, S. (2014) Counselling uncertainty: Genetics professionals’ accounts of (non)directiveness and trust/distrust. Health, Risk and Society 16 (2): 171-184.

Bergmann, J. (1992) Veiled morality: notes on discretion in psychiatry. In D. Drew and J. Heritage (eds) Talk at Work: Interaction in Institutional Settings, 137-162. Cambridge: Cambridge University Press.

Bergmann, J. (1998) Introduction: Morality in discourse. Research on Language and Social Interaction 31 (3/4): 279-294.

Bergmann, J. (1993) Discreet Indiscretions: The Social Organization of Gossip. New York: Aldine de Gruyter.

Clayman, S. (1992) Footing in the achievement of neutrality: the case of news-interview discourse. In D. Drew and J. Heritage (eds) Talk at Work: Interaction in Institutional Settings, 163-198. Cambridge: Cambridge University Press.

Cocking, C. \& Drury, J. (2014) Talking about Hillsborough: 'Panic' as discourse in survivors' accounts of the 1989 football stadium disaster. Journal of Community and Applied Social Psychology 24 (2): 86-99.

Cromdal, J., Osvaldsson, K. \& Persson-Thunqvist, D. (2008) Context that matters: Producing 'thick-enough descriptions’ in initial emergency reports. Journal of Pragmatics 40 (5): 927-959.

Dingvall, R. (1977) ‘Atrocity stories’ and professional relationships. Sociology of Work and Occupations 4 (4): 371-396.

Drew, P. (1992) Contested evidence in courtroom cross-examination: the case of a trial for rape. In P. Drew and J. Heritage (eds) Talk at Work: Interaction in Institutional Settings, 470-520. Cambridge: Cambridge University Press.

Goodwin, M. (1990) Tactical uses of stories: Participation frameworks within girls’ and boys’ disputes. Discourse Processes 13 (1): 33-71.

Harris, S. (2001) Fragmented narratives and multiple tellers: Witness and defendant accounts in trials. Discourse Studies 3 (1): 53-74.

Ingrids, H. (2014) Blame-account sequences in child-custody disputes. Discourse and Society 25 (1): 1-18.

Jayyusi, L. (1991) Values and moral judgment: communicative praxis as moral order. In G. Button (ed) Ethnomethodology and the Human Sciences, 227-251. Cambridge: Cambridge University Press.

Linell, P. \& Rommetveit, R. (1998) The many forms and facets of morality in dialogue: Epilogue for the special issue. Research on Language and Social Interaction 31 (3/4): 465-473.

Karlsson, M., Löfdahl, A. \& Prieto, H. (2013) Morality in parents’ stories of preschool choice: Narrating identity positions of good parenting. British Journal of Sociology of Education 34 (2): 208-224.

Maynard, D. (1996) On 'realization' in everyday life: The forecasting of bad news as a social relation. American Sociological Review 61 (1): 109-131.

Mäkitalo, A. (2006) Effort on display: Unemployment and the interactional management of moral accountability. Symbolic Interaction 29 (4): 531-555.

Osvaldsson, K. (2011) Bullying in context: Stories of bullying on an internet discussion board. Children and Society 25 (4): 317-327.

Patterson, A., Cromby, J., Brown, S., Gross, H. \& Locke, A. (2011) “It all boils down to respect doesn’t it?”: Enacting a sense of community in a deprived inner-city area. Journal of Community and Applied Social Psychology 21 (4): 342-357.

Sacks, H. (1972) Notes on police assessment of moral character. In D. Sudnow (ed) Studies in Social Interaction, 280-293. New York: Free Press.

Sacks, H. (1992) Lectures on Conversation. Oxford: Blackwell.

Sandlund, E. (2014) Prescribing conduct: Enactments of talk or thought in advice-givining sequences. Discourse Studies 16 (5): 645-666.

Solberg, J. (2011) Activation encounters: Dilemmas of accountability in constructing clients as 'knowledgeable'. Qualitative Social Work 10 (3): 381-398.

Svahn, J. \& Evaldsson, A-C. (2013) Talking moral stances into being: The interactional management of moral reasoning in Aggression Replacement Training (ART) classroom sessions. Text and Talk 33 (6): 793-815.

Svennevig, J. (2012) On being heard in emergeny calls: The development of hostility in a fatal emergeny call. Journal of Pragmatics 44 (11): 1393-1412. 
Theobald, M. \& Danby, S. (2012) A problem of versions: laying down the law in the school playground. In S. Danby and M. Theobald (eds) Disputes in Everyday Life: Social and Moral Orders of Children and Young People, 221-241. Bingley: Emerald.

Tholander, M. (2003) Pupils’ gossip as remedial action. Discourse Studies 5 (1): 101-129.

Thorne, B. (1993) Gender Play: Girls and Boys in School. New Brunswick: Rutgers University Press.

Tileagă, C. (2010) Cautious morality: Public accountability, moral order and accounting for a conflict of interest. Discourse Studies 12 (2): 223-239.

Webb, B. \& Stimson, G. (1976) People's accounts of medical encounters. In M. Wadsworth and D. Robinson (eds) Studies in Everyday Medical Life, 108-122. London: Martin Robertson.

Wetherell, M. \& Edley, N. (1999) Negotiating hegemonic masculinity: Imaginary positions and psychodiscursive practices. Feminism and Psychology 9 (3): 335-56.

Whalen, J., Zimmerman, D. \& Whalen, M. (1988) When words fail: A single case analysis. Social Problems 35 (4): 335-362.

Wieder, L. (1974) Telling the code. In R. Turner (ed) Ethnomethodology: Selected Readings, 144-172. Harmondsworth: Penguin. 